\title{
INVESTIGATION OF CHANGING PHYTIC ACID IN LEGUMINOUS SEEDS DEPENDING ON SOAKING AND SPROUTING CONDITIONS
}

\author{
Yana Biletska \\ ya.belecka@karazin.ua \\ Anna Krivtsova ${ }^{1}$ \\ anna.perepelytsia@karazin.ua \\ ${ }^{1}$ Department of International E-Commerce and Hotel and Restaurant Business \\ V. N. Karazin Kharkiv National University \\ Svobody sq., 4, Kharkiv, Ukraine, 61022
}

\begin{abstract}
The results of studying changes of phytic acid in seeds of soya of "Diamond" variety and ones of chick-pea of "Krasnokutsky - 195" depending on seed soaking and sprouting conditions are presented. The content of phytic acid and changes of phytic globoloids in native soya and chick-pea seeds, sprouted in water, sprouted in the solution of mineral salts, preliminarily washed by the solution of lemon acid $\left(\mathrm{C}_{6} \mathrm{H}_{8} \mathrm{O}_{7}\right)$ were studied.

The research topicality is conditioned by the necessity to develop food technologies using vegetable protein, which agent is soya and chick-pea, and to develop technological methods, favoring phytic acid inactivation.

As a result of the study, it has been established, that a decrease of the phytic acid content in soya and chick-pea seeds is influenced by the sprouting process, and seeds washing by $\mathrm{C}_{6} \mathrm{H}_{8} \mathrm{O}_{7}$ solution $(\mathrm{pH}-3.5)$ is a catalyst of these processes.

Soya seeds, sprouted in the potassium iodide solution (PI), and chick-pea seeds, sprouted in the sodium hydroselenite $\left(\mathrm{NaHSeO}_{3}\right)$, preliminarily washed by $\mathrm{C}_{6} \mathrm{H}_{8} \mathrm{O}_{7}$ solution $(\mathrm{pH}-3.5)$, have less content of phytic acid, comparing with other samples.

The phytic acid content decrease has been proved by a phytic globoloid decrease. It has been established, that the least diameter of a phytic globoloid is inherent to samples of soya, sprouted in PI solution and washed by $\mathrm{C}_{6} \mathrm{H}_{8} \mathrm{O}_{7}$ solution $(\mathrm{pH}-3.5),-3.2 \mathrm{mcm}$, and a sample of chick-pea seeds, sprouted in $\mathrm{NaHSeO}_{3}$ solution, washed by $\mathrm{C}_{6} \mathrm{H}_{8} \mathrm{O}_{7}$ solution $(\mathrm{pH}-3.5)-3.0 \mathrm{mcm}$. An undesirable "pea" smell also disappears.

The established regularities are important for scientists because they allow to widen the assortment of products with vegetable protein, safe for the human organism.
\end{abstract}

Keywords: flour, soya, chick-pea, leguminous sprouted flour, phytic acid, phytic globoloid, anti-nutritive effect.

DOI: $10.21303 / 2504-5695.2020 .001523$

\section{Introduction}

Soya and chick-pea have thousand-year traditions of using for food in nations of Southern-Eastern Asia. "Scientific circles" still discuss if they are healthy or harmful for humans. There are different opinions about soya and chick-pea, from enthusiastic ones "soya and chick-pea - food of XXI century and panacea from diseases" [1,2], to very negative "the content of anti-nutritive substances in leguminous influence health of next generations" [3].

The content of phytic acid in leguminous cause the most distrust to them. Work [4] describes phytic acid as a harmful substance, because it binds compounds, disturbing the function of absorbing mineral substances by the intestine.

Work [5] establishes that everyday consumption of phytic acid in amount more $5 \mathrm{~g}$ during 20 days essentially worsens the biological influence on the human organism. The scientists clinically established that it takes place at the expanse of the fact that phytic acid that penetrates the human organism with food products is able to create complexes with microelements in a form, not assimilated by it. The organism cannot use these substances for satisfying physiological needs and removes them together with metabolic products. 
Scientists' attention is directed on developing technologies, inactivating phytic acid in leguminous seeds [6]. From our point of view, it is possible at soaking in the sprouting process [7].

Realization of this complex of researches is timely and topical, and as far as there are not enough data as to solving the aforesaid questions, it is necessary to deepen and to widen researches in this direction.

\section{Analysis of literary data and stating of the problem}

Analyzing literary sources, it has been established [8] that phytic acid accumulates in soya and chick-pea seeds at their ripening as salts of one- and bivalent cations. Phytic acid is spread along the whole seed lobe with nuclei in the aleurone layer.

Penetrating the acid intestine medium, phytic acid dissolves and gets a negative charge, due to which it begins to react with positively charged ions that biogenic bivalent metals $\left(\mathrm{Zn}^{2+} ; \mathrm{Fe}^{2+}\right.$; $\mathrm{Ca}^{2+} ; \mathrm{Mg}^{2+} ; \mathrm{Mn}^{2+} ; \mathrm{Cu}^{2+}$ ) belong to. Compounds, created at their replacement to the intestine, lose solubility, and as a result, their assimilability is disturbed [9].

The scientists describe the aforesaid chemical process by the extra-phosphorus effect of phytase [10], although it is not connected with the direct effect of phytase, but conditioned by the content decrease of reactive-active phytates.

Works [11] elucidate that the anti-nutritive effect of phytic acid is connected with a low accessibility of phosphorus that, according to the scientists, is not correct because testifies only to its limited accessibility and is not connected with anti-nutritive properties.

A solution of the aforesaid problems may be soaking and sprouting of seeds. This process causes enzymatic transformations and disintegration of phytic acid at the expanse of phytase activation, which in its turn enzymatically disintegrates phytic acid, in such a way reducing its anti-nutritive influence. At disintegration of phytic acid, free phosphate ions, accessible for absorbing, form. It conditions decreasing the negative charge of phytic acid molecules and, as a result, losing the ability to block digestion of proteins and absorption of amino acids and minerals.

Works [12] optimize the production technology of a meat-vegetable product, offer to use sprouted malt of mung leguminous crop seeds, establish the phytase activity increase up to $70 \%$ and phytic acid disintegration by $67 \%$. The scientists determined that phytase activation takes place at such technological operations as soaking and sprouting. Work [13] uses such technological approach for phytic acid inactivation at developing the technology of boiled-smoked sausages for dietary consumption. The use of flour from sprouted leguminous in amount of $10 \%$ at the expanse of decreasing pork lard.

Works [14], establish that the acidity of solutions for washing seeds influences the process of phytic acid inactivation in soya and chick-pea seeds. The solution acidity increase from 3.1 to $4.4 \mathrm{pH}$ units influences enzymatic transformations and disintegration of phytic acid at the expanse of phytase activation. So, for inactivating phytic acid, it is expedient to use weak acid solutions for washing together with the sprouting process.

There is a necessity to study changes of phytic acid in leguminous seeds depending on acidity of the washing solution and sprouting medium.

\section{Aim and tasks of research}

The aim of the work is to study changes of phytic acid in leguminous seeds depending on washing solution and sprouting conditions.

The following tasks were set for attaining this aim:

- to study the content of phytic acid in leguminous seeds depending on acidity of the washing solution and sprouting medium;

- to study changes of phytic globoloids depending on acidity change of the washing solution and soaking solution.

\section{Materials and methods of research}

Research objects were soya seeds of "Diamond" variety and chick-pea seeds of "Krasnokutsky - 195" variety of harvest 2018. Samples of native soya and chick-pea seeds, sprouted in 
water, sprouted in the solution of potassium iodide (PI), sprouted in mineral salts, preliminarily washed by the solution of lemon acid $\left(\mathrm{C}_{6} \mathrm{H}_{8} \mathrm{O}_{7}\right) \mathrm{pH}-3.5$ units were studied. Samples of the studied seed raw material were cultivated at the territory of Kyiv region and given for the experiment by the collection seedbed "Agrotech".

\section{1. Methods, used at studying the phytic acid content}

The phytic acid content was determined by the Latta method, based on phytic acid discoloring by the solution of complex iron disulfosalicylate anion up to the brown color [15].

\section{2. Methods, used at studying phytic globoloids}

The analysis of morphology of phytic globoloids was realized by the microscope JSM-5610 LV, equipped by the system of chemical analyzers EDX JED-2201 JEOL. The experimental samples were studied in the regime of low vacuum using a detector with electrodes displaying. A phytic globoloid of a native seed was represented at 5000 magnification.

A phytic globoloid in the samples of soya seeds, sprouted in the potassium iodine solution (PI) preliminarily washed in $\mathrm{C}_{6} \mathrm{H}_{8} \mathrm{O}_{7}$ solution $(\mathrm{pH}-3.5)$ was represented at 3500 magnification.

\section{Results of studying changes of phytic acid depending on acidity of the seed washing solution and sprouting medium}

Table 1 presents results of studying changes of phytic acid in leguminous seeds depending on acidity of the washing solution and sprouting medium.

\section{Table 1}

Changes of phytic acid in leguminous seeds depending on acidity of the washing solution and sprouting medium

\begin{tabular}{ccc}
\hline No. Experimental sample & Phytic acid, mlg/100 g & Phytic globoloid diameter, mcm \\
\hline 1 & $5.5 \pm 0.02$ & $6.5 \pm 0.02$ \\
2 & $2.4 \pm 0.03$ & $5.2 \pm 0.02$ \\
3 & $1.9 \pm 0.02$ & $4.4 \pm 0.03$ \\
4 & $0.6 \pm 0.03$ & $3.2 \pm 0.03$ \\
5 & $5.1 \pm 0.01$ & $6.2 \pm 0.02$ \\
6 & $2.2 \pm 0.03$ & $5.4 \pm 0.03$ \\
7 & $1.4 \pm 0.02$ & $4.5 \pm 0.01$ \\
8 & $0.5 \pm 0.01$ & $3.0 \pm 0.03$
\end{tabular}

Characteristic of the experimental samples:

- experiment 1 - native soya seed (not sprouted);

- experiment 2 - soya seed, sprouted in water, washed by water;

- experiment 3-soya seed, sprouted in the PI solution, washed by water;

- experiment, 4- soya seed, sprouted in the PI solution, washed by $\mathrm{C}_{6} \mathrm{H}_{8} \mathrm{O}_{7}$ solution $(\mathrm{pH}-3.5)$;

- experiment 5- native chick-pea seed (not sprouted);

- experiment 6- chick-pea seed, sprouted in water, washed by water;

- experiment 7- chick-pea seed, sprouted in $\mathrm{NaHSeO}_{3}$ solution, washed by water;

- experiment 8 - chick-pea seed, sprouted in $\mathrm{NaHSeO}_{3}$ solution, washed by $\mathrm{C}_{6} \mathrm{H}_{8} \mathrm{O}_{7}$ solution $\mathrm{pH}-3.5$.

Soya and chic-pea seeds, sprouted in water, washed after sprouting according to the technology of malt production, has phytic acid content 2.4 and $2.2 \mathrm{mlg} / 100 \mathrm{~g}$ that is by 3.1 and $2.9 \mathrm{mgl} / 100 \mathrm{~g}$ (respectively) less comparing with native seeds. The dependence of the phytic acid content on changing $\mathrm{pH}$ of the washing solution has been found, it has been established that at increasing the washing solution acidity, the phytic acid content decreases.

Soya seeds, sprouted in the potassium iodide solution and chick-pea seeds, sprouted in the sodium hydroselenite solution, washed by water for cleaning, have the phytic acid content as 1.9 and $1.4 \mathrm{mlg} / 100 \mathrm{~g}$ (respectively) that is by 1.3 and $0.9 \mathrm{mlg} / 100 \mathrm{~g}$ more, comparing with the samples 
of soya and chick-pea, where $\mathrm{C}_{6} \mathrm{H}_{8} \mathrm{O}_{7}$ solution ( $\mathrm{pH}$ - 3.5) was used for disinfection, where the content reached 0.6 and $0.5 \mathrm{mlg} / 100 \mathrm{~g}$. The phytic acid content decrease was proved by the phytic globoloid diameter decrease. The microphotos of changes of phytic globoloids are presented on Fig. 1. Under condition of measurement magnification: $a-5000$ magnification; $b-d-3500$ magnification of the microscope JSM-5610 LV.

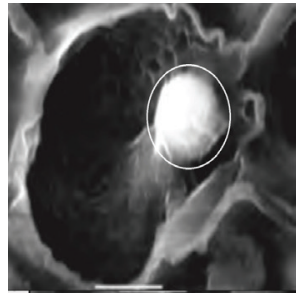

$a$

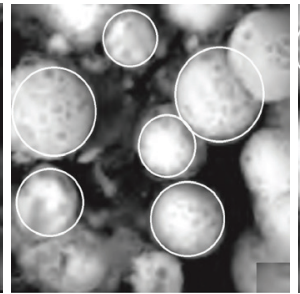

$b$

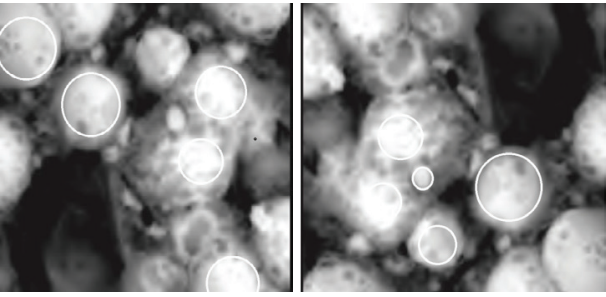

$d$

Fig. 1. Microphotos of changes of phytic globoloids depending on changing acidity of the washing solution and sprouting medium: $a$ - native soya seed, $\mathrm{d}$ (phytic globoloid) $-6.5 \mathrm{mcm}$; $b-\mathrm{H}_{2} \mathrm{O}$, d (phytic globoloid) - $5.2 \mathrm{mcm} ; c-\mathrm{H}_{2} \mathrm{O}+\mathrm{PI}, \mathrm{d}$ (phytic globoloid) $-4.4 \mathrm{mcm}$; $d-\mathrm{C}_{6} \mathrm{H}_{8} \mathrm{O}_{7}(\mathrm{pH}-3.5) \rightarrow \mathrm{H}_{2} \mathrm{O}+\mathrm{PI}, \mathrm{d}$ (phytic globoloid) $-3.2 \mathrm{mcm}$

In the sample with native seeds of leguminous and one, sprouted and washed in water, the phytic globoloid diameter decreases from 6.5 to $5.2 \mathrm{mcm}$ (for soya) and from 6.2 to $5.4 \mathrm{mcm}$ (for chick-pea).

Comparing the sprouted samples in different mediums, washed with the solutions of different acidity, we can see that the least phytic globoloid diameter is inherent to soya ones, sprouted in the PI solution and washed by $\mathrm{C}_{6} \mathrm{H}_{8} \mathrm{O}_{7}$ solution $(\mathrm{pH}-3.5)-3.2 \mathrm{mcm}$ and one of chick-pea seeds, sprouted in $\mathrm{NaHSeO}_{3}$ solution, washed by $\mathrm{C}_{6} \mathrm{H}_{8} \mathrm{O}_{7}$ solution $(\mathrm{pH}-3.5)-3.0 \mathrm{mcm}$.

The effect from using the process of soaking in mineral salts and washing seeds by $\mathrm{C}_{6} \mathrm{H}_{8} \mathrm{O}_{7}$ solution at $\mathrm{pH} 3.5$ units results in disintegration of phytic acid under the influence of phytase, loss of a part of phosphate groups and formation of compounds that cannot retain mineral substances, proteins and amino acids. The undesirable "pea" smell also disappears.

The regularities of changes of biochemical processes in leguminous seeds, which analysis gives a possibility to develop a technology of sprouted leguminous flour (of soya and chick-pea) have been established.

The conducted experimental studies are rather important for scientists, developing technologies of flour of sprouted leguminous, using soya and chick-pea as a main raw material.

\section{Conclusions}

The conducted research on studying changes of phytic acid in leguminous seeds depending on soaking and sprouting conditions allowed to establish the regularities as to the content of phytic acid and changes of phytic globoloids.

1. The content of phytic acid in leguminous seeds depending on acidity of the washing solution and sprouting medium has been determined. It has been established, that the decrease of the phytic acid content in soya and chick-pea seeds is influenced by the sprouting process, and seeds washing by $\mathrm{C}_{6} \mathrm{H}_{8} \mathrm{O}_{7}$ solution $(\mathrm{pH}-3.5)$ is a catalyst of these processes. Soya seeds, sprouted in the potassium iodide solution, and chick-pea seeds, sprouted in the sodium hydroselenite solution, washed by water for cleaning, have the phytic acid content as 1.9 and $1.4 \mathrm{mlg} / 100 \mathrm{~g}$ (respectively) that is by 1.3 and $0.9 \mathrm{mlg} / 100 \mathrm{~g}$ more, comparing with the samples of soya and chick-pea, where $\mathrm{C}_{6} \mathrm{H}_{8} \mathrm{O}_{7}$ solution $(\mathrm{pH}-3.5)$ was used for disinfection, where the content reached 0.6 and $0.5 \mathrm{mlg} / 100 \mathrm{~g}$.

2. The change of phytic globoloids depending on changing acidity of the washing solution and sprouting medium has been studied. It has been established, that the least phytic globoloid diameter is inherent to soya ones, sprouted in the PI solution and washed by $\mathrm{C}_{6} \mathrm{H}_{8} \mathrm{O}_{7}$ solution, which acidity is $3.5,-3.2 \mathrm{mcm}$ and one of chick-pea seeds, sprouted in $\mathrm{NaHSeO}_{3}$ solution, washed by $\mathrm{C}_{6} \mathrm{H}_{8} \mathrm{O}_{7}$ solution $(\mathrm{pH}-3.5)-3.0 \mathrm{mcm}$. 
The effect from using the process of soaking in mineral salts and washing seeds by $\mathrm{C}_{6} \mathrm{H}_{8} \mathrm{O}_{7}$ solution at $\mathrm{pH} 3.5$ units results in disintegration of phytic acid under the influence of phytase, loss of a part of phosphate groups and formation of compounds that cannot retain mineral substances, proteins and amino acids. The undesirable "pea" smell also disappears.

The obtained regularities are important for the scientific community and may be a base for developing food technologies, where inactivation of phytic acid in leguminous seeds is needed for increasing the biological value of developed products.

\section{References}

[1] Biletska, Y., Plotnikova, R., Skyrda, O., Bakirov, M., Iurchenko, S., Botshtein, B. (2020). Devising a technology for making flour from chickpea enriched with selenium. Eastern-European Journal of Enterprise Technologies, 1 (11 (103)), 50-58. doi: https://doi.org/10.15587/1729-4061.2020.193515

[2] Biletska, Y., Djukareva, G., Nekos, A., Husliev, A., Krivtsova, A., Bakirov, M. et. al. (2020). Investigation of change of quality indicators of gluten-free bread during storage. Eastern-European Journal of Enterprise Technologies, 5 (11 (107)), 54-61. doi: https://doi.org/10.15587/1729-4061.2020.215019

[3] Kholina, V. N., Yakovlev, T. A. (2008). World soybean market in the view of regional food security (late XX - early XXI century). Vestnik Rossiyskogo universiteta druzhby narodov. Seriya: Ekonomika, 4, 37-43. Available at: https://cyberleninka.ru/ article/n/dinamika-mirovogo-rynka-soi-v-kontekste-regionalnoy-prodovolstvennoy-bezopasnosti-konets-hh-nachalo-hhi-vv

[4] Fitynova kyslota: koryst i shkoda, v yakykh produktakh mistytsia. Available at: https://ideas-center.com.ua/?p=12996

[5] Rubilar, M., Gutiérrez, C., Verdugo, M., Shene, C., Sineiro, J. (2010). Flaxseed as a source of functional ingredients. Journal of soil science and plant nutrition, 10 (3), 373-377. doi: https://doi.org/10.4067/s0718-95162010000100010

[6] Bohdanov, H. O., Holovchenko, O. V., Arsenieva, L. Yu., Bondar, N. P. (2004). Perspektyvy ta bezpechnist vykorystannia nasinnia biloho liupynu dlia vyrobnytstva kharchovykh produktiv. Visnyk ahrarnoi nauky, 11, 57-61.

[7] Biletska, Y., Semeniuk, A., Perepelytsia, A. (2020). Research of the influence of soybean germination on changes in the amino acid composition and the content of phytic acid. Technology Audit and Production Reserves, 2 (3 (52)), 35-37. doi: https://oi.org/ 10.15587/2312-8372.2020.199524

[8] Sasakawa, N., Sharif, M., Hanley, M. R. (1995). Metabolism and biological activities of inositol pentakisphosphate and inositol hexakisphosphate. Biochemical Pharmacology, 50 (2), 137-146. doi: https://doi.org/10.1016/0006-2952(95)00059-9

[9] Sirko, Ya. M., Kyryliv, B. Ya., Kystsiv, V. O., Lisna, B. B., Galushchak, L. I. (2014). Antioxidant status of chicken's organism in critical periods of growth and development with the additional introduction mineral supplement in their diet. Naukovo-tekhnichnyi biuleten Instytutu biolohiyi tvaryn i Derzhavnoho naukovo-doslidnoho kontrolnoho instytutu vetpreparativ ta kormovykh dobavok, 15 (1), 77-83. Available at: http://nbuv.gov.ua/UJRN/Ntbibt_2014_15_1_16

[10] Joyce, C., Deneau, A., Peterson, K., Ockenden, I., Raboy, V., Lott, J. N. A. (2005). The concentrations and distributions of phytic acid phosphorus and other mineral nutrients in wild-type and low phytic acid Js-12-LPA wheat (Triticum aestivum) grain parts. Canadian Journal of Botany, 83 (12), 1599-1607. doi: https://doi.org/10.1139/b05-128

[11] Titok, V. V., Vakula, S. I., Leontev, V. N. (2015). Analiz strukturnikh kachestvenykh osobenostei deponirovaniia fitina v zrelykh semenakh lna maslichnogo. Tsitoloiia i genetika, 49 (1), 40-45.

[12] Kazymov, S. A., Prudnikova, T. N. (2012). Germination influence on amino acids composition of mash beans. Izvestiya vysshih uchebnyh zavedeniy. Pishchevaya tehnologiya, 5-6, 25-26. Available at: https://cyberleninka.ru/article/n/vliyanie-proraschivaniya-na-aminokislotnyy-sostav-bobov-masha

[13] Biletska, Y., Djukareva, G., Ryzhkova, T., Kotlyar, O., Khaustova, T., Andrieieva, S., Bilovska, O. (2020). Substantiating the use of germinated legume flour enriched with iodine and selenium in the production of cooked-smoked sausages. Eastern-European Journal of Enterprise Technologies, 3 (11 (105)), 46-54. doi: https://doi.org/10.15587/1729-4061.2020.204796

[14] Torres, J., Domínguez, S., Cerdá, M. F., Obal, G., Mederos, A., Irvine, R. F. et. al. (2005). Solution behaviour of myo-inositol hexakisphosphate in the presence of multivalent cations. Prediction of a neutral pentamagnesium species under cytosolic/ nuclear conditions. Journal of Inorganic Biochemistry, 99 (3), 828-840. doi: https://doi.org/10.1016/j.jinorgbio.2004.12.011

[15] Latta, M., Eskin, M. (1980). A simple and rapid colorimetric method for phytate determination. Journal of Agricultural and Food Chemistry, 28 (6), 1313-1315. doi: https://doi.org/10.1021/jf60232a049 